\title{
Photovoltaic and wind energy: challenges and solutions in desert regions
}

\author{
Ali Al-Dousari*, Waleed Al-Nassar, and Modi Ahmed
}

Kuwait Institute for Scientific Research, Environmental and Life Sciences Research Center, Al-Jaheth Str., Shuwaikh, 13109, Kuwait

\begin{abstract}
In desert areas, some challenges have the prospective to reduce photovoltaic energy production. These are the creation of finely crusted carbonates and/or mud coatings resulted from fallen aerosols and dust during humid conditions. These challenges that greatly affect solar panel planes, as well as wind turbines, were allocated to accomplish the practicability to establish wind and/or photovoltaic energy systems in Kuwait. It was concluded that solar cells are not the best appropriate energy source in Kuwait due to the above-listed challenges; therefore, substitute renewable energy types are considered more practicable. After one year of operation at photovoltaic units and wind turbines in Kuwait, the outcomes show that wind turbines record production energy numbers that go beyond the production average. This was connected with high capacity factors during one year, consequential in an annual power production that is 2.3 times greater than that of solar panels; running 450 homes compared to 199 homes for photovoltaic (PV). Bubiyan Island and west of Kuwait are the most suitable potential location for wind farm establishment. Several control measures including the establishment of green belts and plantation of native shrubs were found proper in reducing dust by $64.5 \%$ and 68.4 , respectively.
\end{abstract}

\section{Introduction}

Globally, the consumption of wind and solar energy is expected to increase more than any other mid-century energy source [1]. Solar and wind energy as a renewable energy source, therefore, conquer the peak between various alternative energy sources and are slowly adapted in multiple applications [6]. In desert regions, several environmental problems affect the photovoltaic panel such as darkness, air pollution and dust. Wind and photovoltaic energy are quiet, abundant, environmentally friendly, and a renewable energy source [8]. Solar radiation, dust and relative humidity in the Middle East have a negative impact on the Arabian Gulf region [13]. Such a challenge is common in nature and is therefore likely to apply passive and active approaches in desert regions according to their specific conditions [9]. At a certain geographic location, awareness of these challenges is vital in establishing any clean energy systems and in estimating their output and efficiency [3]. Awareness of these challenges is also a prerequisite for all solar and wind systems to be modeled and planned and valuable for studies on the balance of atmospheric energy, air quality and climate [14]. The concerns of social public engagement and sustainable expansion in the region, solar energy development are discussed along with the necessity to develop the human capital needed to address alternative photovoltaic energy challenges from a technical and social point of view [10]. In addition, wind energy efficiency problems require the careful attention of wind properties such as average wind frequency distribution and speed [14].

The Gulf Countries (Saudi Arabia, Qatar, Kuwait, UAE, Oman, and Bahrain) are at peak loads deficiency and high risk of power, in addition to consuming oil and gas resources to meet increasing energy demand [4]. In Kuwait, environmentally clean energy systems will lead to a modern electrical network, more job opportunities, a more efficient power supply, and a better regional image in a cleaner environment [11]. Among the many alternative renewable energy sources, photovoltaic power generation is the most practiced in the Arabian Gulf countries [2]. The monthly solar consumption in Kuwait is approximately $9-11 \mathrm{hr} / \mathrm{d}$ with a mean daily solar insolation of more than $7.0 \mathrm{kWh} / \mathrm{m}^{2}$ [8]. On the other hand, aeolian dust is a common weather phenomenon in marine and terrestrial [1] environments within Kuwait. In the northern Arabian Gulf, including Kuwait, there are more dusty days compared to the southern part [5]. In Kuwait, the mean total annual dusty days is 255 days which definitely will act as a challenge for solar power generation in the region. Therefore, place Kuwait as an ideal location for investigating the significant effect of dust and weather challenges on the generation of solar and wind energy generation. The aim of this study is to determine the potential feasibility of setting up solar and/or wind energy systems in Kuwait focusing on the environmental challenges. This study covers successful control measures that were applied to control or minimize the effect of such challenges.

* Corresponding author: adousari@kisr.edu.kw 


\section{Methodology}

\subsection{The depositional dust rates and weather data}

In Kuwait, humidity and average solar radiation data (2010-2016) were attained from 9 weather stations. The solar radiation was measured via the Li-COR pyranometer fixed at a 10-meter above ground level in all weather stations.

Fallen dust amounts were monitored for two years (September 2009 - August 2011) from 47 locations in Kuwait using dust collectors following Reheis (1995) design that was (Figure 1). The trap is $240 \mathrm{~cm}$ in height and with a $20 \mathrm{~cm}$ radius from ground level (Figure 2). The deposited dust was collected every month from all traps.

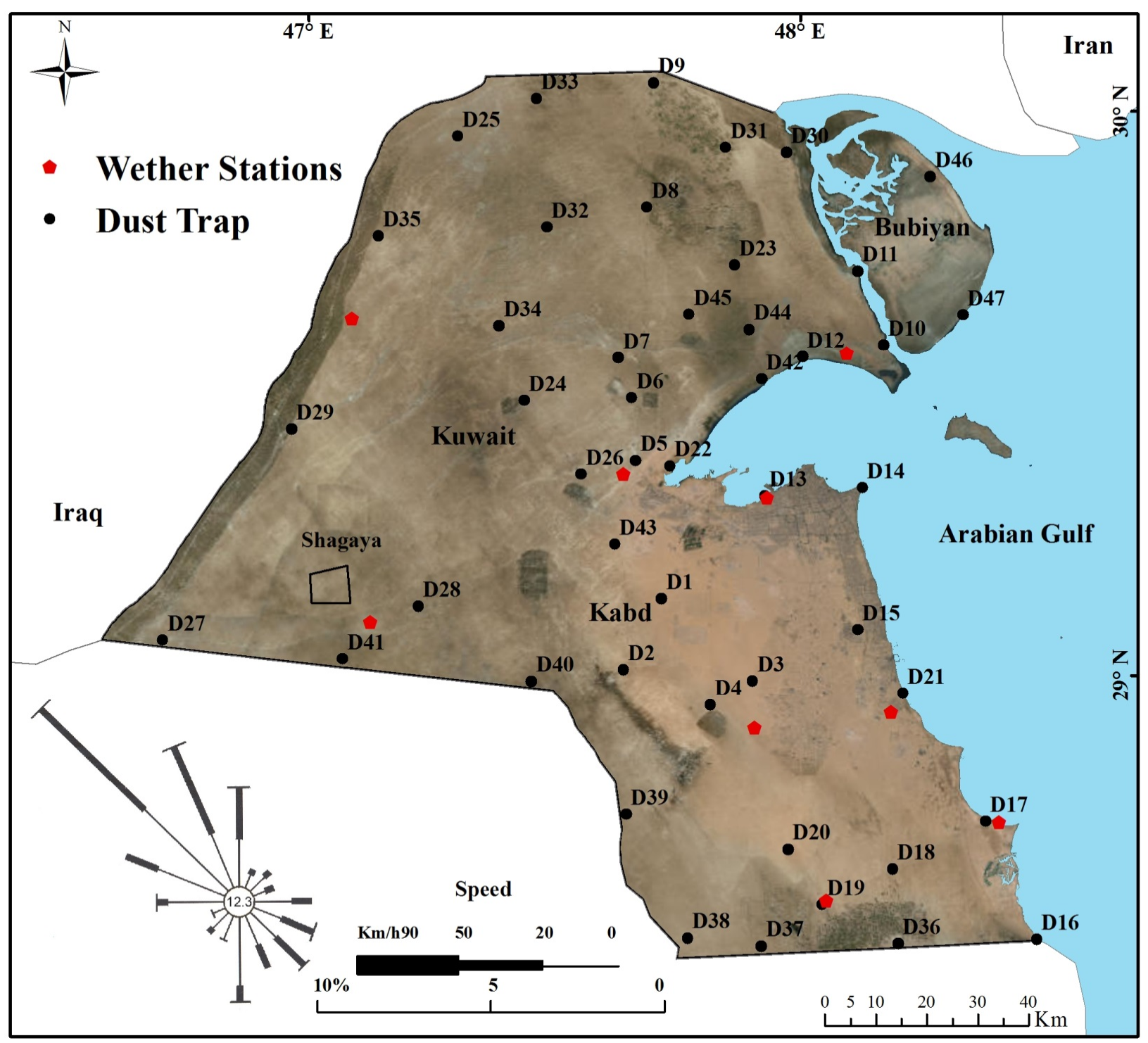

Fig. 1. Location map for the weather (1958-2016) and dust (2009-2011) monitoring stations with the average wind rose for Kuwait and showing the Shagaya area.

The wind and solar energy power plants with 10MW capacity each, located in the Shagaya area west of Kuwait were compared (Figure 3). The wind is represented by five wind turbines ( $2 \mathrm{MW}$ for each) that were fixed near the photovoltaic energy unit. The wind and PV farms were studied from an economic point of view with reference to their Levelized Cost of Electricity. The monthly capacity factor was calculated for a one-year operation (June 2017 to July 2018). Annual production of both plants was measured; Capital Expenditure and operation expenditure were taken into concern throughout the life of the plants together with Investment cots.

\subsection{Carbonates and Mud in dust}

Dust fallout particle size percentages were identified via sieve mesh (63 micrometers) to separate sand from mud for all samples for four months (November, August, May and February 2010). Also, the carbonates (mainly calcite and dolomite) within collected dust samples during 
March, June, September, and December were identified using Philips PW-1830 X-ray diffraction (XRD).

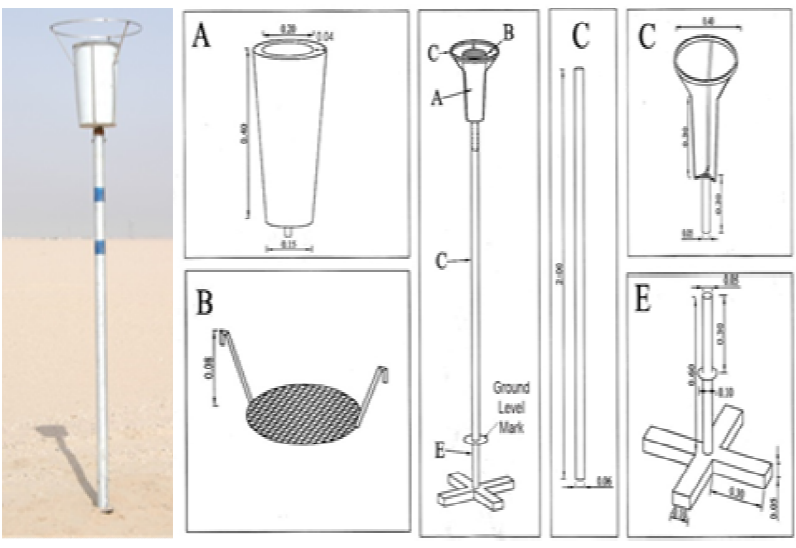

Fig. 2. The dust trap (left photo) and diagram (right sketches).
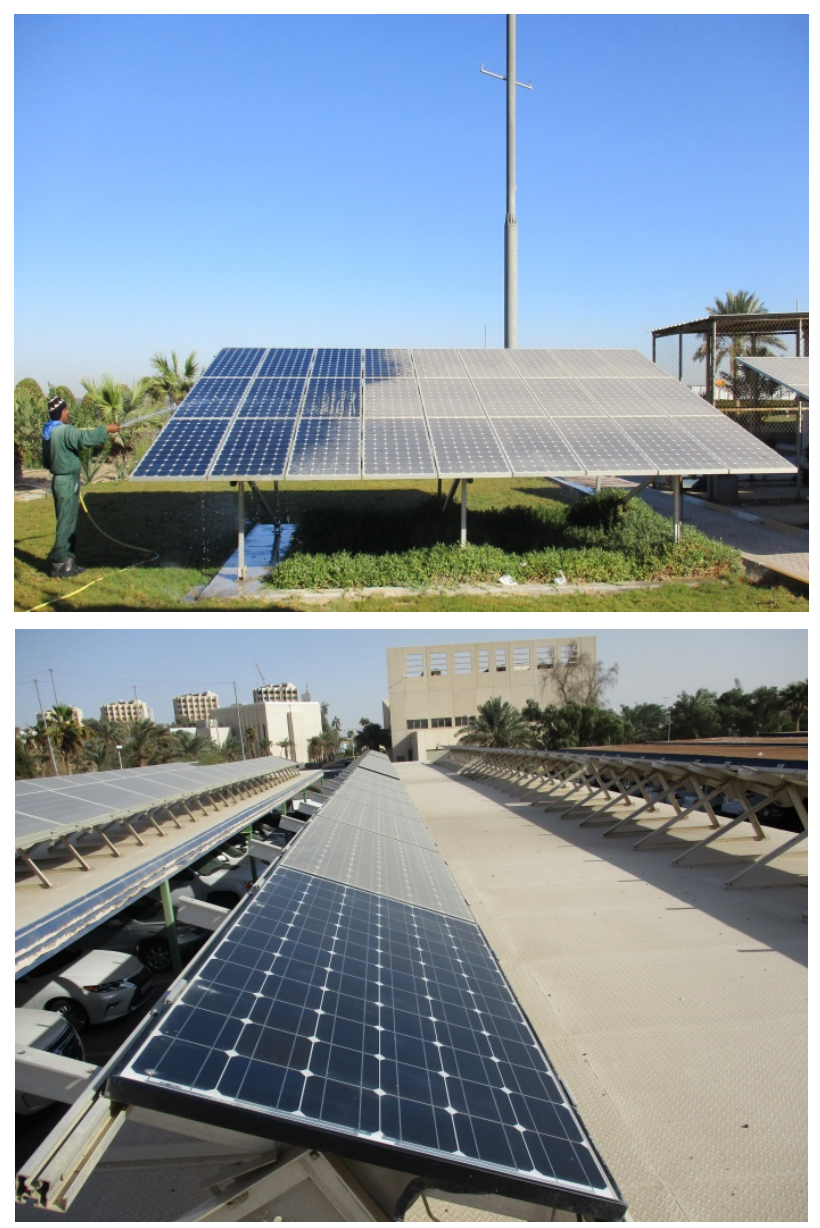

Fig. 3. Dusty solar panels compared to cleaned panels at the KISR.

\subsection{Mapping}

The collected data for depositional dust rates, mud and carbonates percentages, humidity, solar radiations, and wind were stored as layers using the ArcGIS S/W software, and geostatistical interpolator (Simple IDW method) was steered to create the annual average distribution maps.

Approximately 110 thousand native plants
(Haloxylon salicornicum, Lycium shawii, Nitraria retusa, and Calligonum polygonoides) were planted at a 3-m average distance between plants in highly degraded land with no vegetation. Both five sand and dust traps were fixed (2 at $100 \mathrm{~m}$ downwind, 2 at $100 \mathrm{~m}$ upwind, and 1 in control area) for monitoring the aeolian deposition (dust and mobile sand) monthly for four years (September 2011-August 2015).

\section{Results and Discussion}

The annual dust deposition rates are 149-576 $\mathrm{t} \mathrm{km}$ (average is $339 \mathrm{t} \mathrm{km}^{-2}$ ) in 2010-2011 and 10-1065 $\mathrm{t} \mathrm{km}^{-2}$ (average is $216 \mathrm{t} \mathrm{km}^{-2}$ ) in 2009-2010. The average dust rate maps were delineated based on the average annual dust deposition in two years 2009-2010 (Fig. 4a) and 2010-2011(Fig. 4b). These maps show momentous trends in dust accumulation over the two years of monitoring. The maps classify specific spaces with high (more than $350 \mathrm{t} \mathrm{km}^{-2}$ ) and low dust deposition in the two years, but the spaces with high dust deposition extend to cover more places in 2010-2011 compared to 2009-2010. This will surely will affect solar energy in Kuwait and the surrounding regions. The effect of dust on solar or wind energy production was globally and regionally addressed by many researchers.

The deposition of dust on surfaces of photovoltaic cells can increase cleaning cost which is considered necessary to ensure the minimization of efficient operation and power leakage. Dust deposits on photovoltaic cells, combined with a lack of water sources in the desert regions to clean the solar-power system will add a variable cost for cleaning services. Dust can have a damaging effect on the operating potential of photovoltaic plants. Dust was revealed to degrade the energy delivery, which in turn causes a decrease in the energy output of photovoltaic cells by $15 \%$ to $30 \%$ [15]. Power fall can even reach $100 \%$ during humid periods with dust concentration by watersoluble salts.

\subsection{The mud content}

The mud is particles that are less than 4 phi $(0.063 \mathrm{~mm})$ in size diameter. Mud contains two major size fractions; these are silt and clay. It was noted that the southern areas in Kuwait contain fewer mud percentages compared to northern Kuwait. Deposited dust during February revealed the lowest mud ratios when compared to other months, while November and August revealed the highest. The annual mud percentages present in accumulated dust range from $10-95 \%$, with $63 \%$ as an average (Fig. 4c). Globally, the mud highest percentages $(\geq 85 \%)$ within dust are recorded in Cairo - Egypt, Um Qasir - Iraq, Manamah - Bahrain, Cartagena Colombia, and Bald Hill - Australia.

\subsection{The carbonates content}

Carbonates and quartz form the main constituent of dust mineralogy in Kuwait (Table 1). 

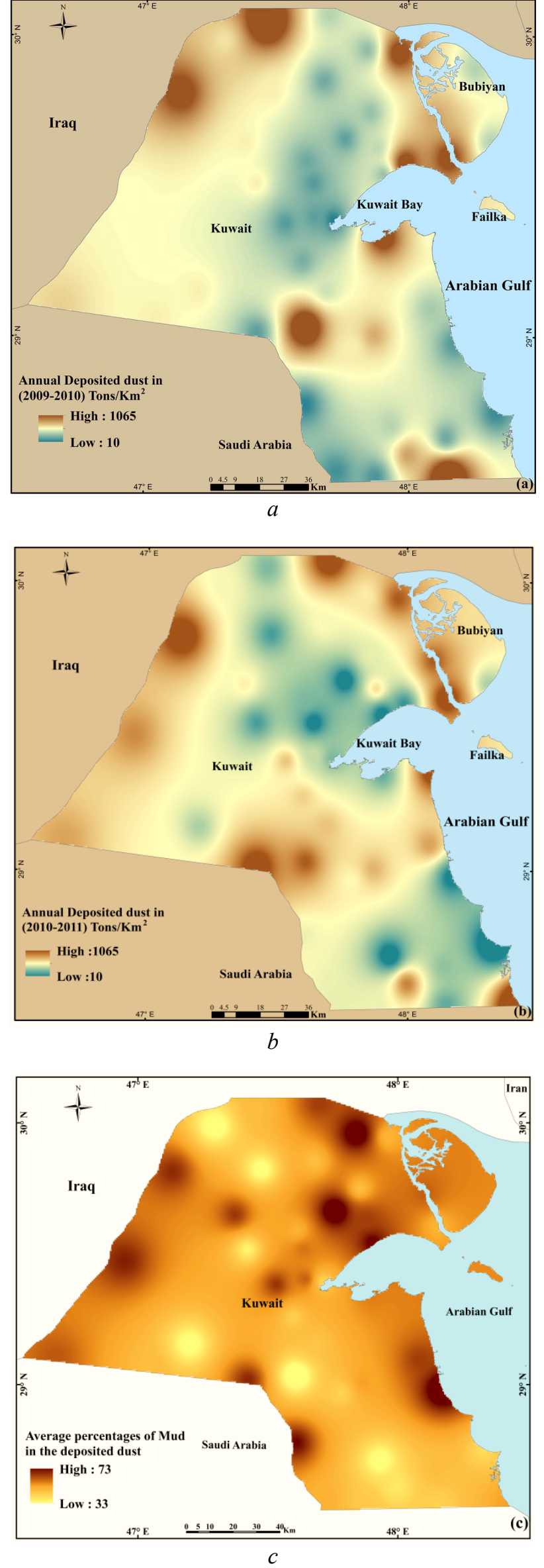
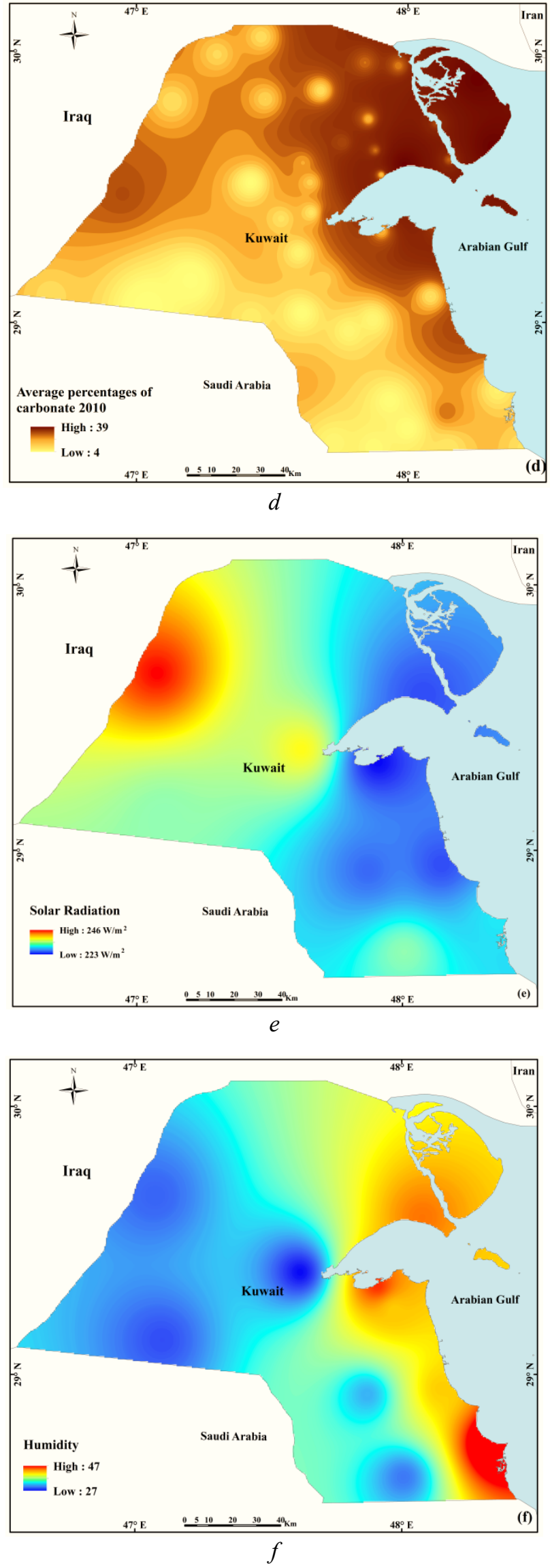

Fig. 4. Maps for annual deposited dust in 2009-2010 (a) and 2010-2011 (b), average mud and carbonate percentages within dust (c, d), and average solar radiation and humidity (e, f). 
Table 1. The mineralogical percentages and average particle size of dust in Kuwait compared to global dust samples.

\begin{tabular}{|l|c|c|c|c|c|c|c|}
\hline \multirow{2}{*}{ Location } & \multicolumn{2}{|c|}{$\begin{array}{c}\text { Particle } \\
\text { size \% }\end{array}$} & \multicolumn{5}{|c|}{ Minerals \% } \\
\cline { 2 - 8 } & Sand & Mud & $\begin{array}{c}\text { Car- } \\
\text { bo- } \\
\text { nates }\end{array}$ & $\begin{array}{c}\text { Qu- } \\
\text { artz }\end{array}$ & $\begin{array}{c}\text { Feld- } \\
\text { spars }\end{array}$ & Clay & Others \\
\hline Kuwait & 37 & 63 & 45 & 38 & 10 & 2 & 5 \\
\hline Ain - Emirates & 97 & 4 & 52 & 26 & 20 & 1 & 0 \\
\hline $\begin{array}{l}\text { Dubai - } \\
\text { Emirates }\end{array}$ & 17 & 82 & 45 & 21 & 6 & 0 & 27 \\
\hline Ahwar - Iraq & 3 & 97 & 80 & 13 & 8 & 0 & 0 \\
\hline $\begin{array}{l}\text { Manama - } \\
\text { Bahrain }\end{array}$ & 12 & 87 & 41 & 32 & 10 & 3 & 15 \\
\hline $\begin{array}{l}\text { Walameen - } \\
\text { Saudi Arabia }\end{array}$ & 40 & 61 & 13 & 62 & 24 & 1 & 0 \\
\hline $\begin{array}{l}\text { Amman - } \\
\text { Jordan }\end{array}$ & 30 & 70 & 68 & 21 & 4 & 0 & 7 \\
\hline Tripoli - Libya & 20 & 81 & 27 & 64 & 5 & 4 & 0 \\
\hline $\begin{array}{l}\text { Biougra - } \\
\text { Morocco }\end{array}$ & 12 & 88 & 46 & 46 & 8 & 1 & 0 \\
\hline $\begin{array}{l}\text { Cartagena - } \\
\text { Colombia }\end{array}$ & 10 & 90 & 0 & 66 & 33 & 0 & 1 \\
\hline $\begin{array}{l}\text { Bald Hill - } \\
\text { Australia }\end{array}$ & 9 & 90 & 0 & 57 & 21 & 14 & 7 \\
\hline Cairo - Egypt & 10 & 90 & 34 & 51 & 15 & 0 & 0 \\
\hline Average & 25 & 75 & 38 & 41 & 14 & 2 & 5 \\
\hline Maximum & 97 & 97 & 80 & 66 & 33 & 14 & 27 \\
\hline
\end{tabular}

The dust contains higher carbonate percentages during October-April reaching up to $58 \%$. The presence of higher carbonate percentages acts as a good indication for low aeolian activity during summer (MaySeptember). The northwestern and western areas show the lowest percentages down to $5 \%$ of the total mass of dust. The average annual carbonate percentages within the deposited dust range from 4 to $36.8 \%$ with $27.6 \%$ as average (Fig. 4d). The highest carbonate percentages are in the northeastern parts of Kuwait and coastal areas. Kuwait, Bahrain, and Dubai contain nearly similar amounts of carbonates in dust samples. On the other hand, carbonates vary a lot in other regional areas such as Al-Ahwar and Um Qasir - Iraq (Table 1). This is attributed to the dust storms that originate from Iran and Iraq is rich in mud and carbonates [7].

\subsection{The solar radiation}

The average annual solar radiations on the horizontal surfaces in Kuwait are represented geographically (Fig. 4e). The average annual solar radiation ranges from $223 \mathrm{Wm}^{-2}$ to $246 \mathrm{Wm}^{-2}$ which is so low. The northwestern and north areas in Kuwait reveal higher solar radiation compared to other areas.

The average humidity similar to solar radiation, coastal areas show higher percentages while other areas show lower humidity percentages (Fig. 4f). The carbonates and/or mud mixed with humidity causing the development of a thin-crust layer on solar panels that are difficult to clean. Numerous cleaning can effect, scratch and damage to solar panels.

\subsection{Solar photovoltaic (PV) and wind energy}

After one year of operation at photovoltaic units and wind turbines in Kuwait, the outcomes show that wind turbines record production energy numbers that go beyond the production average. This was connected with high capacity factors during one year, consequential in an annual power production that is 2.3 times greater than that of solar panels; running 450 homes compared to 199 homes for PV (Figure 5, Table 2).
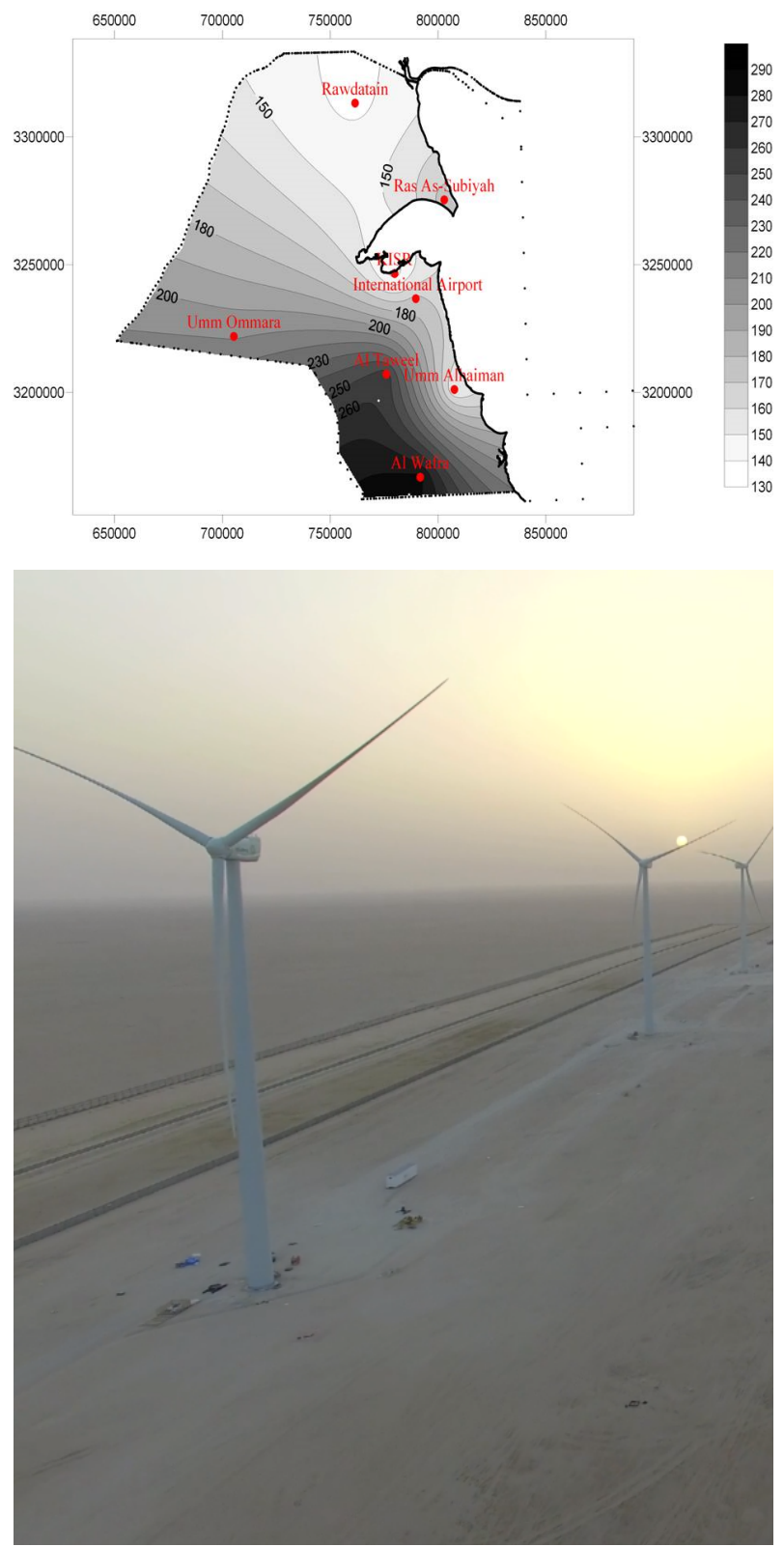

Fig. 5. A map for wind power density $\mathrm{W} / \mathrm{m}^{2}$ distribution over Kuwait at a height of $30 \mathrm{~m}$ (top) and the wind turbines in the Shagaya area at western Kuwait (bottom).

Similar to solar radiation, coastal areas show higher percentages while other areas show lower humidity percentages (Fig. 4f). The carbonates and/or mud mixed with humidity causing the development of a thin-crust layer on solar panels that are difficult to clean. Numerous cleaning can effect, scratch and damage to solar panels. 
Table 2. The Shagaya Wind and PV Farms economic results.

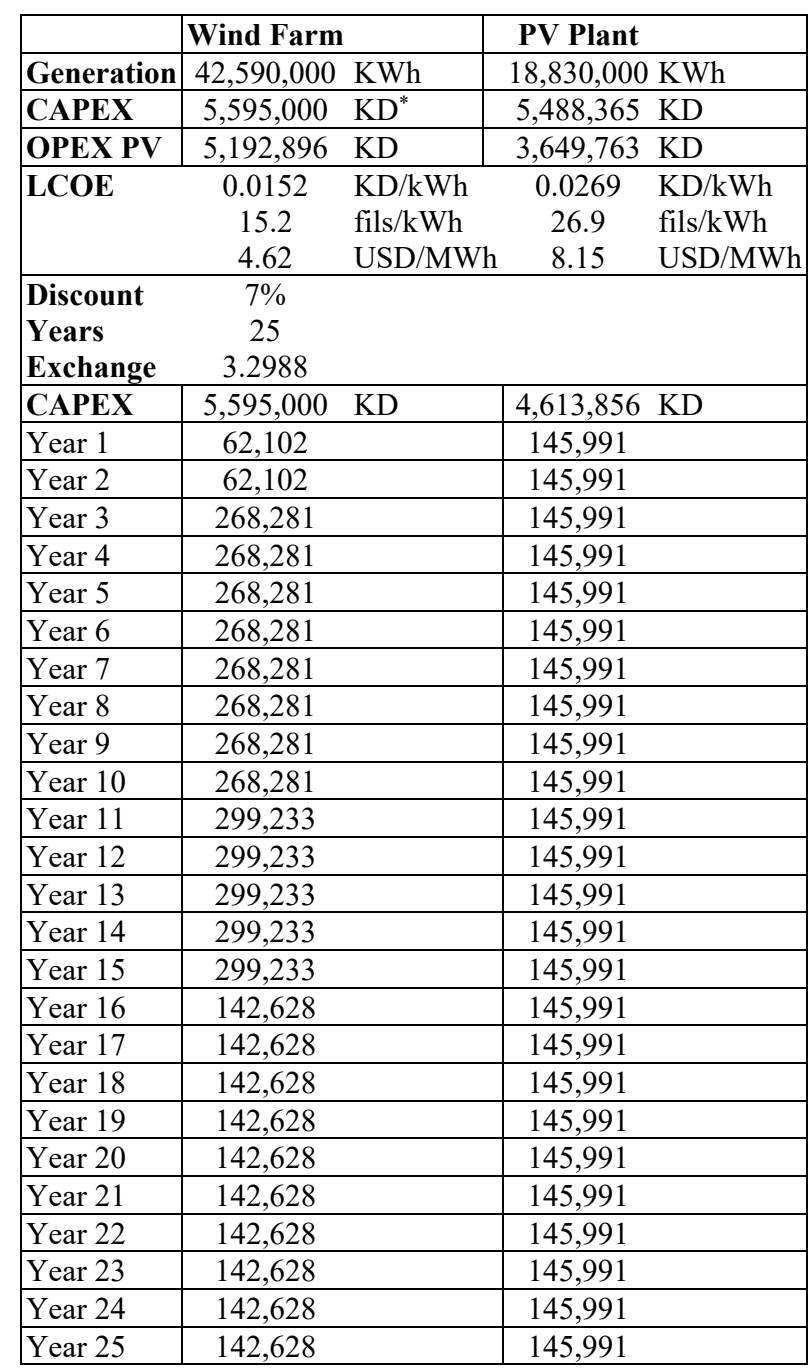

KD : Kuwait Dinar

\section{Conclusions}

The Arabian Gulf governments recently proposed a strategy for the expansion in using sustainable energy mainly photovoltaic energy with a more ambitious vision to act as a solar and wind energy exporter. This study has positively identified the surrounded challenges that can disturb the performance of photovoltaic technologies in the desert region. On the other hand, the development of photovoltaic energy units in Kuwait and the Gulf countries should take into concern environmental challenges, such as fallen dust, and mud, carbonates, humidity, and solar radiation. The effect of dust (depositional rates, mud and carbonate contents), solar radiation and humidity on the power efficiency of photovoltaic panels were observed. Therefore, wind as an alternative source of energy would be more feasible. The Bubiyan Island, southwestern and western sides of the state of Kuwait and southern are the potential sites for wind farm establishment. Several control measures including the establishment of green belts and plantation of native shrubs were found proper in reducing dust by $64.5 \%$ and 68.4 , respectively.
This project was funded by the KFAS (Kuwait Foundation for the Advancement of Science) and KISR (Kuwait Institute for Scientific Research) grant number $(2008,1401,01)$. Thanks are extended to National Meteorological Network at KISR for their support with meteorological data.

\section{References}

1. A. Aba, A.M. Al-Dousari, A. Ismaeel, J. Rad-anal. Nucl. Chem. 307(1), 15-23 (2016).

2. A. Aba, A.M. Al-Dousari, A. Ismaeel, J. Env. radio. 192, 565-572 (2018)

3. M. Ahmed, A.M. Al-Dousari, Kuwait J. Sci. 40(1), 165-178 (2013)

4. A.M. Al-Dousari, A. Al-Hazza, Arab. J. Geosci. 6(2), 519-527 (2013)

5. A.M. Al-Dousari, in Desertification in arid lands, ed. by N.R. Bhat, A. Al-Nasser, S. Omar (eds). (KISR, 2009), pp. 137-147

6. A.M. Al-Dousari, A. Aba, S. Al-Awadhi, M. Ahmed, N. Al-Dousari, Arab. J. Geosci. 9(2), 95 (2016).

7. A. Al-Dousari, D. Doronzo, M. Ahmed, Sustain. 9(9), 1526 (2017)

8. A.M. Al-Dousari, M. Ahmed, N. Al-Dousari, S. AlAwadhi, Int. J. Environ. Sci. Tech. 16(5), 24152426 (2019).

9. A. Al-Dousari, W. Al-Nassar, A. Al-Hemoud, A. Alsaleh, A. Ramadan, N. Al-Dousari, M. Ahmed, Energy 176, 184-194 (2019)

10. A.M. Al-Dousari, A. Alsaleh, M. Ahmed et al, Earth Syst Environ. 3(3), 471-482 (2019)

11. E. Al Enezi, A. Al-Dousari, F. Al-Shammeri, J. Eng. Res. 2(2), 1-14 (2016)

12. A.N. Al-Ghadban, A. Al Dousary, P.G. Jacob, M. Behbehani, P. Cacers, Tokyo University of Fisheries, Tokyo, Japan, 65-88 (1998)

13. D.M. Doronzo, A.M. Al-Dousari, A. Folch, P.D. Waldhauserova, Arab. J. Geosci. 9, 468 (2016)

14. S. Neelamani, A.M. Al-Dousari, Arab. J. Geosci. 9, 210 (2016)

15. N. Middleton, Aeol. Res. 24, 53-63 (2017)

16. M.C. Reheis, J. Geophys. Res. 100, 8893-8918 (1995) 